\title{
Pistacia vera $L$. hosts pistachio ampelovirus A in Tunisia
}

\author{
Ghada Chouk $^{1,3} \cdot$ Manel Elair $^{1} \cdot$ Azza Chelli Chaabouni $^{2} \cdot$ Toufic Elbeaino $^{3} \cdot$ Michele Digiaro $^{3} \cdot$ Naima Mahfoudhi $^{1}$ (1)
}

Received: 12 June 2021 / Accepted: 5 July 2021 / Published online: 9 July 2021

(c) Società Italiana di Patologia Vegetale (S.I.Pa.V.) 2021

Keywords Pistachio · Ampelovirus · Germplasm

Pistachio (Pistacia vera L.) is an important crop in Tunisia. With a 30.000 ha of cultivated area, Tunisia is the $7^{\text {th }}$ largest pistachio producer in the world. The country has long been engaged in selecting local cultivars and ecotypes for establishing a national germplasm collection. Little is known on the sanitary status of this species, in particular on the presence of viruses. Given the growing interest in pistachio cultivation, a study was carried out to ascertain the virus status of this crop in Tunisia. The attention was paid to the detection of pistachio ampelovirus A (PAVA) of the family Closteroviridae that was recently reported in pistachio in the USA (Al Rwahnih et al. 2018). The survey was conducted in the Tunisian germplasm collection plot, which is under rainfed conditions at the Northeastern part of the country and represents the main national source of pistachio plant propagation material for nurseries. Leaf samples from 130 accessions (males and females) were collected. Total nucleic acids were extracted following the CTAB buffer method of Murray and Thompson (1980). All samples were tested by RT-PCR for the presence of PAVA using a specific primer pair designed in the heat shock protein 70 homolog coding region (Al Rwahnih et al. 2018) to amplify a genomic fragment of $516 \mathrm{bp}$ in size. Fifteen samples $(11.5 \%)$ were found infected with PAVA. The presence

Naima Mahfoudhi

nmahfoudhi@yahoo.fr

1 Laboratoire de Protection Des Végétaux, Université de Carthage, Institut National de La Recherche Agronomique de Tunisie, Rue Hedi Karray, 1004 ElMenzah, LR16INRAT04 Tunis, Tunisia

2 Laboratoire D'Horticlture, Université de Carthage, Institut National de La Recherche Agronomique de Tunisie, Rue Hedi Karray, 1004 ElMenzah, LR16INRAT03 Tunis, Tunisia

3 Istituto Agronomico Mediterraneo Di Bari, Via Ceglie 9, 70100 Valenzano, Bari, Italy of PAVA in pistachio was confirmed by sequencing RT-PCR amplicons of three infected accessions, whose nucleotides sequences deposited in GenBank under accession numbers MZ357211-MZ357213 showed $99.1 \%$ of identity with isolate W10 (MF198462) from the USA. This is the first report of PAVA in pistachio in Tunisia.

Data availability The sequencing data generated in this study were deposited in the GenBank and will be freely available to any researcher.

\section{Declarations}

Informed consent All authors have approved the submission of this manuscript.

Conflict of interest The authors declare that they have no conflict of interest.

\section{References}

Al Rwahnih M, Rowhani A, Westrick N, Stevens K, Diaz-Lara A, Trouillas FP, Preece J, Kallsen C, Farrar K, Golino D (2018) Discovery of viruses and virus-like pathogens in pistachio using high-throughput sequencing. Plant Dis 102:1419-1425. https:// doi.org/10.1094/PDIS-12-17-1988-RE

Murray MG, Thompson WF (1980) Rapid isolation of higher weight DNA. Nucleic Acids Res 8(19):4321-4325

Publisher's Note Springer Nature remains neutral with regard to jurisdictional claims in published maps and institutional affiliations. 